\title{
Vitamin D nutrition in pregnant women at term and in newly born babies in Saudi Arabia
}

\author{
F SERENIUS, ${ }^{*}$ ATH ELIDRISSY, $\dagger$ P DANDONA $\ddagger$
}

From the Departments of Paediatrics, *King Feisal Hospital and †King Saud University, Riyadh, Saudi Arabia, and the $¥$ Metabolic Unit, Department of Chemical Pathology, Royal Free Hospital and School of Medicine, London NW3 2QG

SUMMARY A survey to assess the vitamin D nutritional state in 119 pregnant women at term and in their newborns was undertaken in Riyadh, Saudi Arabia. Concentrations of 25-hydroxy vita$\min \mathrm{D}(25-(\mathrm{OH}) \mathrm{D})$ were below $4 \mathrm{ng} / \mathrm{ml}$ in 30 of 119 maternal sera, in 11 of which they were undetectable. The median concentration of $25-(\mathrm{OH}) \mathrm{D}$ was $5.7 \mathrm{ng} / \mathrm{ml}$, which is comparable to that found in Asian vegetarian women at term in London. Fifty of 119 cord samples had undetectable $25-(\mathrm{OH}) \mathrm{D}$, and a total of 81 samples had 25- $(\mathrm{OH}) \mathrm{D}$ concentrations of less than $4 \mathrm{ng} / \mathrm{ml}$. Despite the low 25-(OH)D concentrations cord bloods had calcium concentrations higher than those in maternal blood, while serum albumin concentration was similar in maternal and cord samples. Higher socioeconomic background of women, antenatal care, and vitamin D supplementation were associated with significantly higher concentrations of $25-(\mathrm{OH}) \mathrm{D}$. Vitamin D supplementation, however, had no significant effect on 25- $(\mathrm{OH}) \mathrm{D}$ concentration in cord samples or on the weight of the newborns.

This study shows the high prevalence of marginal vitamin D nutrition in women in Saudi Arabia, which may predispose babies to rickets during infancy. In a country endowed with plentiful sunshine, the exclusion of sunshine by thick dark veils and bad housing probably contribute to this marginal state of vitamin $\mathrm{D}$ nutrition.

The two major sources of vitamin $\mathrm{D}$ in the body are the diet and the skin. Dietary vitamin $\mathrm{D}$ is obtained from animal sources, and hence vegetarian diets are notorious for the lack of this vitamin.' The synthesis of vitamin $\mathrm{D}$ in the skin depends on exposure to ultraviolet rays from the sun ${ }^{2-4}$; the lack of sunshine in a country such as the UK can curtail exposure of the skin to the sun to an extent that people on vegetarian diets-for example, Asian immigrants in the UK-may develop a deficiency of vitamin D. ${ }^{5-8}$ This deficiency may be corrected spontaneously during the summer. ${ }^{9}$ It is, however, difficult to conceive of vitamin $D$ deficiency in a setting where most people are non-vegetarian and where there is plentiful sunshine. It was therefore surprising that rickets was found frequently in preschool children in Saudi Arabia.

In view of this finding we embarked on a study of vitamin D state in that section of the population of Saudi Arabia most vulnerable to lack of vitamin D-that is, the pregnant women and their newly delivered babies. Since the demands of vitamin D

Accepted for publication 4 January 1984 increase during pregnancy, such a study would provide an index of marginal vitamin $D$ nutrition and might also define those neonates who would be potential candidates for developing rickets in infancy.

\section{Material and methods}

Seventy five percent of the mothers studied were selected at random from the Maternity and Children's Hospital in Riyadh. This hospital handles 20000 deliveries each year, which would account for most of the childbirths in that city. Thus our patient sample was fairly representative of the low and middle socioeconomic groups. Of the mothers included in this study $25 \%$ were delivered at King Feisal Specialist Hospital and Research Centre, Riyadh; these mothers were mostly from the upper socioeconomic group. Assessment of birth weight and length was carried out by one of the investigators ( $\mathrm{AE}$ or $\mathrm{FS})$, and the gestational age was assessed simultaneously by the method of Parkin. Patients were classified into three socioeconomic groups-upper, middle, and lower-using information obtained from a detailed questionnaire. The fol444 
lowing factors were taken into consideration: the mother's literacy, years of schooling, and ability to speak a foreign language; the husband's literacy, schooling, ability to speak a foreign language, and occupation; and the type of house they lived in.

In order to obtain blood samples, prior consent from the mother and hospital director was obtained. Premature infants and those delivered by caesarian section and their respective mothers were excluded from the study. Cord blood was obtained while the placenta was still in situ. The cord was cut with a sterile blade and blood was allowed to drip into tubes.

Some of the blood was heparinised, centrifuged, and separated into plasma while the rest was allowed to clot, centrifuged, and separated into serum. Samples were stored at $-20^{\circ} \mathrm{C}$ until analysis. Blood samples were obtained from the forearm veins of the mothers within $5 \mathrm{~min}$ of delivery and were handled as above. The blood samples were obtained randomly throughout the year.

Plasma samples were used for the measurement of calcium, phosphate, alkaline phosphatase, and albumin concentrations on a SMAC (Technicon) autoanalyser.

The serum concentration of $25-(\mathrm{OH}) \mathrm{D}$ was measured by a method modified from that of Preece $e t$ $a l^{10}$; this entailed a preparatory chromatographic step followed by a protein binding step. Statistical analysis was carried out by Student's $t$ test, MannWhitney $U$ test, and $\chi^{2}$ test as appropriate.

\section{Results}

CALCIUM, PHOSPHATE, AND ALKALINE PHOSPHATASE

Plasma calcium concentration in umbilical vein blood was consistently higher than that in maternal samples. The mean maternal calcium ( $\pm \mathrm{SD}$ ) was $2 \cdot 22 \pm 0 \cdot 10 \mathrm{mmol} / \mathrm{l}$, whereas that in the fetus was $2.60 \pm 0.15 \mathrm{mmol} / \mathrm{l}(\mathrm{p}<0.001)$. Mean plasma calcium concentrations in maternal or cord blood obtained from subjects with low 25-(OH)D concentrations $(<4 \mathrm{ng} / \mathrm{ml})$ were not significantly different to those from the rest.

Plasma calcium concentrations in mothers from the higher socioeconomic group were not significantly different from those in mothers from the lower socioeconomic group, as was the case with cord blood samples. Plasma albumin concentrations in maternal and cord blood samples were similar.

Alkaline phosphatase activity was considerably higher in maternal plasma than in cord plasma in all but 10 samples. Six of these 10 samples were associated with extremely low or undetectable 25$(\mathrm{OH}) \mathrm{D}$ concentrations in maternal and cord blood.
Table 1 Serum 25-hydroxy vitamin D concentrations $(\mathrm{ng} / \mathrm{ml})$ in maternal and cord bloods at delivery: the effect of socioeconomic status

\begin{tabular}{lll}
\hline & Maternal & Cord \\
\hline $\begin{array}{l}\text { Upper class } \\
\text { (n=27) }\end{array}$ & $7 \cdot 0$ & $3 \cdot 3$ \\
Middle class & $(3 \cdot 2-20)$ & $(3-12)$ \\
$(\mathrm{n}=58)$ & $5 \cdot 5$ & $3 \cdot 0$ \\
Lower class & $(3-21 \cdot 8)^{*}$ & $(3-16 \cdot 3)$ \\
$(\mathrm{n}=33)$ & $4 \cdot 8$ & $3 \cdot 0$ \\
\hline
\end{tabular}

${ }^{*} p<0.01$ when compared with no vitamin D supplements.

Median 25-hydroxy vitamin D concentration in sera of vegetarian Asian women at term at the Royal Free Hospital was $8 \mathrm{ng} / \mathrm{ml}$ $(n=15)$.

Values given as mean (range).

Alkaline phosphatase isoenzymes were not measured.

\section{5-HYDROXY VITAMIN D}

In 11 of 119 maternal samples and in 50 of 119 cord samples $25-(\mathrm{OH}) \mathrm{D}$ was undetectable (less than 3 $\mathrm{ng} / \mathrm{ml})$. In a further 19 maternal samples and 31 cord samples $25-(\mathrm{OH}) \mathrm{D}$ concentrations were extremely low (less than $4 \mathrm{ng} / \mathrm{ml}$ ). Concentrations below $4 \mathrm{ng} / \mathrm{ml}$ are found in sera of Asian vegetarian osteomalacic patients in the $\mathrm{UK}^{8}$ In all but three cases the concentration of $25-(\mathrm{OH}) \mathrm{D}$ was lower in the newborns than in their respective mothers. In these three cases maternal cord differences were minimal and were within the precision range of the assay. There was a highly significant correlation $(r=$ $0.8, p<0.001)$ between the concentrations of 25-(OH)D in maternal and cord sera.

\section{EFFECT OF SOCIOECONOMIC STATUS}

Maternal serum concentrations of 25-(OH)D were significantly greater in the upper socioeconomic group than that in the middle and low socioeconomic groups (Table 1). In the latter two groups the 25-(OH)D concentration was extremely low ( $3 \mathrm{ng} / \mathrm{ml}$ or less, often undetectable) in 11 of 91 cases $(12 \%)$. No mother from the upper socioeconomic group had such low concentrations of this metabolite. There was no difference in 25$(\mathrm{OH}) \mathrm{D}$ concentration between the middle and low socioeconomic groups.

Neonatal 25-(OH)D concentration was not affected by the mother's socioeconomic class. Neither the median 25-(OH)D concentration nor the frequency of extremely low concentrations was different in various socioeconomic groups.

EFFECT OF VITAMIN SUPPLEMENTATION Concentrations of $25-(\mathrm{OH}) \mathrm{D}$ were significantly greater in mothers who had been given vitamin $D$ supplements during pregnancy than in those who had not $(\mathrm{p}<0.01)$ (Table 2$)$. Values were similar 
Table 2 Serum 25-hydroxy vitamin D concentrations ( $\mathrm{ng} / \mathrm{ml}$ ) in maternal blood: the effect of vitamin $D$ supplementation

\begin{tabular}{lll}
\hline & $\begin{array}{l}\text { Median } \\
25-(\mathrm{OH}) \mathrm{D} \text { less than } 4 \mathrm{ng} / \mathrm{ml}\end{array}$ \\
\hline $\begin{array}{l}\text { Vitamin D supplementation } \\
\text { during pregnancy (n= 73) }\end{array}$ & $7 \cdot 42^{*}$ & $13 \dagger$ \\
$\begin{array}{l}\text { No supplementation } \\
\text { during pregnancy }(\mathrm{n}=43)\end{array}$ & $5 \cdot 25$ & 25 \\
$\begin{array}{l}\text { Vitamin D supplementation } \\
\text { during third trimester (n }=53)\end{array}$ & $7 \cdot 44^{*}$ & \\
$\begin{array}{l}\text { No supplementation during } \\
\text { third trimester }(\mathrm{n}=59)\end{array}$ & $5 \cdot 80$ \\
\hline
\end{tabular}

${ }^{*} p<0.01$ when compared with no vitamin D supplements, tp $<0.05$ when compared with no vitamin $D$ supplements, No information was available for three patients for entire pregnancy and for seven for the last trimester.

among those who had been given supplements throughout pregnancy. As expected, the prevalence of very low concentrations of $25-(\mathrm{OH}) \mathrm{D}$ was significantly greater $(p<0.05)$ in mothers who had no vitamin $\mathrm{D}$ supplements during pregnancy (25 of $43 v 13$ of 73). The concentration of $25-(\mathrm{OH}) \mathrm{D}$ in mothers given supplements during pregnancy was similar to that in mothers from the upper socioeconomic group. Thus the class based differences found in this study may to some extent reflect the effects of vitamin D supplementation and good antenatal care. Of mothers from the upper socioeconomic class $96 \%$ were on vitamin D supplements, whereas only $55 \%$ and $50 \%(p<0.01)$ of mothers from the middle and lower socioeconomic groups respectively were on antenatal vitamin D supplements. Looked at in another way, nine of 11 mothers who had just detectable or undetectable concentrations of $25-(\mathrm{OH}) \mathrm{D}$ had had no vitamin supplement during pregnancy. Neonatal concentrations of this metabolite were not significantly affected by vitamin $\mathrm{D}$ supplementation.

\section{EFFECT OF ANTENATAL CARE}

Mothers who had no antenatal care had significantly lower (median 6.4; range 3-6.5) (p<0.05) 25$(\mathrm{OH}) \mathrm{D}$ concentrations than those who had at least one antenatal visit to the hospital for assessment (median 7; range 4-21.7). Antenatal care and the frequency of visits to the hospital were once again related to the socioeconomic class of the mother: all mothers from the upper class had some antenatal care, whereas 26 of 91 mothers $(30 \%)$ from the other two groups had no antenatal care at all.

\section{BIRTH WEIGHT}

Babies' weights at birth were not related to 25$(\mathrm{OH}) \mathrm{D}$ concentrations. The mean birth weight of babies with $25-(\mathrm{OH}) \mathrm{D}$ concentrations of less than $4 \mathrm{ng} / \mathrm{ml}(3.31 \mathrm{~kg})$ was not significantly different from that of babies whose vitamin D concentrations were greater than $10 \mathrm{ng} / \mathrm{ml}(3.40 \mathrm{~kg})$. The class origin of the mother had no effect on the birth weight of babies in our series.

\section{Discussion}

The most important message to emerge from our data is that vitamin $D$ deficiency occurs in a significant proportion of pregnant Saudi women at term, and this is in a country which has more sunshine than any other and where no one is a vegetarian. The undetectable or extremely low concentrations of $25-(\mathrm{OH}) \mathrm{D}$ in $25 \%$ of Saudi pregnant women are comparable to those of Dent and Gupta ${ }^{8}$ and Heckmatt et al ${ }^{11}$ and also our own data for non-pregnant and pregnant Asian women in the UK.

Concentrations of $25-(\mathrm{OH}) \mathrm{D}$ in umbilical blood samples were even lower than those in maternal blood. Forty two percent of umbilical samples had either undetectable or extremely low concentrations of this vitamin D metabolite. The umbilical 25$(\mathrm{OH}) \mathrm{D}$ concentrations, though related closely to those in maternal blood, were consistently lower than the latter even when the concentration of this metabolite was extremely low. This confirms the concept of concentration dependent passage of this vitamin $D$ metabolite across the placenta, as has been shown previously in pregnant women with normal vitamin $D$ concentrations. ${ }^{1-14}$ In this respect it is difficult to account for the contradictory observations of Heckmatt et al, who found that the mean 25-(OH)D concentrations in cord blood were consistently higher than those in maternal blood." Further clarification in this regard is also necessary because the concentration of vitamin $\mathrm{D}$ binding protein in umbilical samples has been shown to be significantly different from that in maternal samples. ${ }^{1516}$ The ratios of concentrations of free vitamin $D$ in maternal and umbilical blood may thus be different from those suggested by our data. The absence of a significant effect of vitamin D supplementation on cord blood concentrations of 25 $(\mathrm{OH}) \mathrm{D}$ cannot be explained readily. It may reflect an accelerated $1 \alpha$-hydroxylase activity in the placenta and a greater rate of conversion of 25$(\mathrm{OH}) \mathrm{D}$ to 1,25 dihydroxy vitamin $\mathrm{D}$. Such an increase in the latter would also explain the maintenance of the relatively normal concentrations of calcium in the neonate, as well as the transplacental transport of calcium against a concentration gradient.

It is noteworthy that none of the 27 women from the upper socioeconomic class had extremely low concentrations of $25-(\mathrm{OH}) \mathrm{D}$. The mean $25-(\mathrm{OH}) \mathrm{D}$ concentration in this group was also significantly higher than that in women of the other two 
socioeconomic classes. This difference is probably due to better diet, greater exposure to sun, and better housing. It is important to mention in this respect that (a) mothers of the upper socioeconomic class also had better antenatal care and vitamin supplementation and (b) the disadvantage of the middle and lower socioeconomic class was to some extent offset by antenatal care and vitamin D supplementation.

It is of interest that the umbilical blood samples had consistently higher calcium concentrations than those in the mothers, despite little or no difference in albumin concentrations of the mother and the newborn. This had been observed previously in pregnancies not interfered with by $25-(\mathrm{OH}) \mathrm{D}$ deficiency. ${ }^{17}{ }^{18}$ It would thus appear that the transport of calcium by the placenta has to be carried out actively against a concentration gradient. ${ }^{19}$ The significance of, and the mechanism underlying, the higher fetal concentration of calcium (largely due to ionised calcium in view of the lack of differences in albumin concentrations) is not clear. It is, however, worth mentioning that the placenta synthesises calcium binding protein and $1 \alpha$-hydroxylase enzyme required for the activation of vitamin $D .^{20}$

The cause of the low concentrations of vitamin D in Saudi women, as stated above, is neither a vegetarian diet nor the lack of sunshine. It is probably due to the exclusion of sunlight by the use of dark veils and thick garments outdoors and also due to badly illuminated housing. Exposure to sunlight is an important determinant of serum $25-(\mathrm{OH}) \mathrm{D}$ concentrations in pregnant women ${ }^{12}$; deliberate exclusion of sunlight appears to be the most important factor in our series.

While considering supplementation with vitamin D in Saudi women in the antenatal period, it is worth mentioning that the concentration of 25$(\mathrm{OH}) \mathrm{D}$ in women given supplements was lower than that found in Asian women in the UK given oral supplements of vitamin $\mathrm{D}$. This difference was observed in spite of the fact that there was no difference between Asian women in the UK and Saudi women not receiving vitamin supplements. This raises questions about compliance to treatment in the case of Saudi women: one would be led to suggest that the vitamin $D$ supplements in pregnant mothers should be given as single bolus injections of calciferol. Such a regimen has been shown to be effective among Asian osteomalacics. ${ }^{21}$

We thank Miss L McLoughlin for technical assistance and Mrs J Singh and Mrs P Dale for secretarial assistance.

\section{References}

' Norman AW. Vitamin D: the calcium homeostatic steroid hormone. In: Darby J, ed. Nutrition: Basic and applied science.
New York: Academic Press, 1979:417.

${ }^{2}$ Huldschinsky K. Heilung von rachitis durch Kunstliche Hohensonne. Dtsch Med Wochenschr 1979;45:712-3.

${ }^{3}$ Hess AF, Unger LJ. Cure of infantile rickets by sunlight. Preliminary notes. J Am Med Assoc 1921;77:39-40.

${ }^{4}$ Holick MF, Maclaughlin JA, Clark MB, et al. Photosynthesis of previtamin $D_{3}$ in human skin and physiologic consequences. Science 1980;210:203-5.

${ }^{s}$ Durrigan MG, Paton JPJ, Haases SJ, McNicol GW, Gardner MD, Smith CM. Late rickets and osteomalacia in the Pakistani community in Glasgow. Scott Med J 1961;7:159-67.

- Felton DJC, Stone WD. Osteomalacia in Asian immigrants during pregnancy. $\mathrm{Br}$ Med J 1966;i:1521-2.

' Dent CE, Round JM, Rowe DJF, Stamp TCB. Effect of chapattis and ultraviolet radiation on nutritional rickets in Indian immigrants. Lancet 1973;i:1282-4.

${ }^{8}$ Dent CE, Gupta MM. Plasma 25-hydroxyvitamin D levels during pregnancy in Caucasians and in vegetarian and nonvegetarian Asians. Lancet 1975;ii: 1057-60.

9 Gupta MM, Round JM, Stamp TCB. Spontaneous cure of vitamin D deficiency in Asians during summer. Lancet 1974;i: 586-8.

${ }^{10}$ Preece MA, O' Riordan JLH, Lawson DEM, Kodicek E. A competitive protein binding assay for 25-hydroxy cholecalciferol and 25-hydroxyergocalciferol in serum. Clin Chim Acta 1974;54:235-42.

" Heckmatt JE, Peacock M, Davies AE, McMurray J, Isherwood DM. Plasma 25-hydroxyvitamin D in pregnant Asian women and their babies. Lancet 1979;ii:546-8.

12 Hillman LS, Haddad JG. Perinatal vitamin D metabolism III. Factors influencing late gestational human serum 25hydroxy-vitamin D. Am J Obstet Gynecol 1976;125:96-9.

${ }^{13}$ Hillman LS, Slatopolsky E, Haddad JG. Perinatal vitamin D metabolism IV. Maternal and Cord serum 24, 25 dihydroxyvitamin D concentrations. J Clin Endocrinol Metab 1978;47:1073-8.

${ }^{14}$ Cockburn F, Belton NR, Purvis RJ, et al. Maternal vitamin D intake and mineral metabolism in mothers and their newborn infants. $\mathrm{Br}$ Med J 1980;218:11-3.

is Haddad JG, Walgate J. Radioimmunoassay of binding protein for vitamin D and its metabolites in human serum: concentrations in normal subjects and patients with disorders of mineral metabolism. J Clin Invest 1976;58:1217-26.

${ }^{16}$ Bouillon R, van Assche FA, Van Baelen H, Heynes W, De Moor $P$. Influence of the vitamin $D$ binding protein on serum concentration of 1,25 dihydroxyvitamin $\mathrm{D}_{3} . J$ Clin Invest 1981;67:589-94.

17 Steichen JJ, Tsang RC, Gratton TL, Haustra A, DeLuca HF. Vitamin $\mathrm{D}$ homeostasis in the perinatal period: 1,25 dihydroxyvitamin $\mathrm{D}$ in maternal, cord and neonatal blood. $N$ Engl $\mathrm{J}$ Med 1980;302:315-7.

${ }^{18}$ Kronfeld DS, Ramberg CF, Delvoria-Papadopoulos M. Active transport of calcium across placenta and mammary gland measured in vivo. In: Nichols G, Wasserman RH, eds. Cellular mechanisms for calcium transfer and homeostasis. New York: Academic Press. 1979:339

${ }^{19}$ Christakos S, Norman AW. Purification of the calcium binding protein from human placenta and the identification of specific receptors/binding proteins for 1,25 dihydroxyvitamin $D_{3}$ in both human and rat placenta. J Clin Endocrinol Metab (in press).

${ }^{20}$ Weisman Y, Harrell A, Edelstein S, David M, Spirer Z, Golander A. 1, 25-dihydroxyvitamin $D_{3}$ and 24,25 dihydroxyvitamin $D_{3}$ in vitro synthesis by human decidua and placenta. Nature 1979;281:317-8.

${ }^{21}$ Stephens WP, Klimiuk PS, Berry JL, Mauser EB. Annual highdose vitamin D prophylaxis in Asian immigrants. Lancet 1981;ii: 1199-201.

Requests for reprints to: Dr P Dandona, Metabolic Unit, Department of Chemical Pathology, Royal Free Hospital, Pond Street, London NW3 2QG, England. 